Jan Kluza

ORCID: 0000-0002-0929-6093

Uniwersytet Jagielloński

https://doi.org/10.19195/1733-5779.33.15

\title{
Cywilne środki ochrony dobrego imienia Rzeczypospolitej Polskiej na gruncie nowelizacji ustawy o IPN
}

\author{
JEL Classification: K15
}

Słowa kluczowe: dobra osobiste, Instytut Pamięci Narodowej, zakłamywanie historii

Keywords: personal rights, Institute of National Remembrance, deception of history

Abstrakt: Dnia 28 stycznia 2018 roku uchwalona została ustawa, której zadaniem jest dbanie o dobre imię Polski oraz walka z zakłamywaniem historii. W tym celu wprowadza się odpowiednie środki o naturze cywilnej umożliwiające dochodzenie dobrego imienia Polski, a nie tylko ochrony dóbr osobistych osób indywidualnych. Artykuł przedstawia omówienie cywilnych środków ochrony wizerunku Polski oraz zawiera ich ocenę w kontekście ich wykonalności.

\section{Civil measures to protect the good name of the Republic of Poland on the basis of the amendment to the Act on the Institute of National Remembrance}

\begin{abstract}
On 28 January 2018 the polish parliament passed an act whose task is to take care of the good name of Poland and to fight with the deception of history. To achieve these points, the act introduces appropriate measures of a civil nature. The article presents an overview of civil protection measures for the image of Poland and includes their assessment from the point of view of their feasibility.
\end{abstract}

\section{Wstęp}

Dnia 26 stycznia 2018 roku została uchwalona ustawa ${ }^{1}$, której głównym zamierzeniem jest wzmocnienie prawnej ochrony dobrego imienia Rzeczypospoli-

1 Ustawa z dnia 26 stycznia 2018 roku o zmianie ustawy o Instytucie Pamięci Narodowej Komisji Ścigania Zbrodni przeciwko Narodowi Polskiemu, ustawy o grobach i cmentarzach 
tej Polskiej przed kłamliwymi oskarżeniami w stosunku do Państwa Polskiego. Ustawa ta $\mathrm{w}$ pierwotnej wersji zawierała zarówno cywilne, jak i karne środki, które zdaniem projektodawców mają uskutecznić dochodzenie ochrony prawnej dobrego imienia RP. Na skutek kolejnej nowelizacji przepisy karne wprowadzone tą ustawą zostały jednak uchylone ${ }^{2}$, w związku z czym znaczenia nabiera cywilna ochrona imienia Polski.

\section{Indywidualne naruszenie dóbr osobistych}

Przed przystąpieniem do szczegółowych rozważań na temat nowej regulacji należy wskazać, że już na gruncie wcześniejszego stanu prawnego formułowane były pozwy na drodze cywilnej, a także zapadały wyroki w sprawach o naruszenie dóbr osobistych na gruncie oskarżeń pod adresem Polski. Kategorie dóbr osobistych oraz ich naruszenie należy jednak oceniać przez pryzmat subiektywny i obiektywny. Kryterium subiektywne dóbr osobistych zakłada istnienie indywidualnych dla każdego człowieka wartości związanych z jego stanem psychicznym, natomiast kryterium obiektywne odwołuje się do ocen przyjętych $w$ danym społeczeństwie ${ }^{3}$. Na Portalu Orzeczeń Sądów Powszechnych ${ }^{4}$ do dziś widnieje sześćdziesiąt wyroków w sprawach o posługiwanie się sformułowaniem „polskie obozy”. Praktyka stosowania przepisów o ochronie dóbr osobistych w tego typu sprawach jest jednak różna, co przedstawiają wybrane i szczegółowo dalej omówione orzeczenia. W tego typu sprawach zastosowanie znajduje także obowiązek umieszczenia bezpłatnego sprostowania nieścisłej lub nieprawdziwej wiadomości zawartej w materiale prasowym na podstawie art. 31a prawa prasowego ${ }^{5}$.

W jednej z tego typu spraw, w kwietniu 2016 roku, Sąd Okręgowy w Krakowie oddalił ${ }^{6}$ powództwo kombatanta i byłego więźnia obozu w Auschwitz wytoczone

wojennych, ustawy o muzeach oraz ustawy o odpowiedzialności podmiotów zbiorowych za czyny zabronione pod groźbą kary, Dz.U. poz. 369.

${ }^{2}$ Ustawa z dnia 27 czerwca 2018 roku o zmianie ustawy o Instytucie Pamięci Narodowej Komisji Ścigania Zbrodni przeciwko Narodowi Polskiemu oraz ustawy o odpowiedzialności podmiotów zbiorowych za czyny zabronione pod groźbą kary, Dz.U. poz. 1277.

${ }^{3}$ M. Pazdan, [w:] Kodeks cywilny, t. 1. Komentarz. Art. 1-449 ${ }^{10}$, red. K. Pietrzykowski, Warszawa 2015, s. 109.

${ }^{4}$ Na dzień 6 lutego 2018 roku. W związku z dużą liczbą nowych publikacji po przyjęciu ustawy nowelizującej przez polski parlament można się jednak spodziewać, że ich liczba będzie większa, co już zapowiedział między innymi Polski Związek Byłych Więźniów Politycznych Hitlerowskich Więzień i Obozów Koncentracyjnych (https://olsztyn.tvp.pl/35550683/olsztynscy-prawnicy -przygotowali-kolejne-pozwy-za-polskie-obozy (dostęp: 13.08.2020).

5 Ustawa z dnia 26 stycznia 1984 roku Prawo prasowe, Dz.U. Nr 5, poz. 24.

6 Wyrok Sądu Okręgowego w Krakowie z dnia 26 kwietnia 2016 roku, I C 151/14, https://orzeczenia.ms.gov.pl/content/polskie\$0020obozy/152010000000503_I_C_000151_2014_Uz_2016-0425_001, (dostęp: 13.08.2020). 
przeciwko niemieckiej telewizji ZDF, w którym ten domagał się zakazania używania w jakimkolwiek języku określeń ,„polski obóz zagłady” lub „,polski obóz koncentracyjny", a także wydania stosowanych przeprosin za używane wcześniej tego typu sformułowania o następującej treści:

Z.F., wydawca portalu internetowego www.zdf.de wyraża ubolewanie z powodu pojawienia się w dniu 15 lipca 2013 r. na portalu www.zdf.de w artykule pt. V.F. 1945. D. befreiung der K. nieprawdziwego i fałszującego historię Narodu Polskiego określenia, sugerującego, jakoby obozy zagłady w M. i Auschwitz został wybudowane i prowadzone przez Polaków. Obozy zagłady w M. i Auschwitz, których dotyczy artykuł, były niemieckimi obozami zagłady wybudowanymi w czasie II W. Światowej na okupowanym terenie Polski. Naród Polski nie był ani organizatorem, ani budowniczym tych obozów. Miliony Polaków różnej narodowości stały się ofiarami ludobójstwa dokonanego przez niemieckiego okupanta. Zatem przepraszamy Pana K.T., który był więziony w niemieckim obozie koncentracyjnym, za naruszenie jego dóbr osobistych, w szczególności tożsamości narodowej (poczucia przynależności do Narodu Polskiego) i jego godności narodowej ${ }^{7}$.

\section{W uzasadnieniu wyroku Sąd Okręgowy stwierdził, że}

poczucie przynależności narodowej oraz duma z takiej przynależności mieszczą się w powszechnie i społecznie akceptowanym zestawie wartości, które mogą stanowić ważny element stanu świadomości i uczuć człowieka, a jeśli są wyznawane i kultywowane przez określoną osobę, należy je uznać za jej dobra osobiste podlegające ochronie przewidzianej w art. 23 i 24 k.c. ${ }^{8}$

Sąd uznał więc, że ,strona pozwana, używając w zapowiedzi programowej na swojej stronie internetowej sformułowania »polskie obozy zagłady«, naruszyła dobra osobiste powoda K.T., takie jak godność człowieka, tożsamość narodowa i godność narodowa". Sąd ten stwierdził także, że

nie jest tak, że każdy członek narodu polskiego może czuć się obrażony tego typu sformułowaniem, w tym sensie, że zostały naruszone jego dobra osobiste. Natomiast powód jako były więzień obozu koncentracyjnego, który na własnej skórze przeszedł przez gehennę obozu w Auschwitz, może czuć się obrażony tego typu sformułowaniem, bo przez takie określenie z ofiary staje się sprawcą 9 .

Pomimo zacytowanych konstatacji sąd oddalił jednak powództwo, uznając, że pozwany spełnił żądania powoda — materiał został usunięty ze strony internetowej, a powód został przeproszony w pismach kierowanych do jego pełnomocnika. Zdaniem sądu orzekającego w tej sprawie powód

nie może domagać się szerszych przeprosin, w szczególności takich jak opisane w pozwie, albowiem nie może działać w imieniu narodu polskiego, nie może zastępować władz państwa polskiego, albowiem sprawa zainicjowana przed sądem jest sprawą o ochronę dóbr osobistych powoda, a nie innej osoby bądź osób ${ }^{10}$.
${ }^{7}$ Ibidem.
8 Ibidem.
9 Ibidem.
10 Ibidem.

Studenckie Prace Prawnicze, Administratywistyczne

(C) for this edition by CNS 
W wyniku wywiedzionej jednak od tego wyroku apelacji Sąd Apelacyjny w Krakowie ${ }^{11}$ zmienił zaskarżony wyrok, nakazując telewizji ZDF przeproszenie powoda poprzez umieszczenie stosownego oświadczenia na stronie internetowej telewizji. Sąd ten podzielił stanowisko sądu I instancji, stwierdzając, że „tożsamość i godność narodowa, jak już wskazano, należą do katalogu chronionych dóbr osobistych, zaś w przedmiotowej sprawie został spełniony wymóg indywidualizacji naruszenia", a ponadto

pozwany nie dopełnił adekwatnych czynności mających usunąć skutki naruszenia. Ze względu na formę naruszenia — na publicznie dostępnej stronie internetowej — za właściwe nie można uznać przeprosin listownych, skierowanych wyłącznie do powoda (za pośrednictwem jego pełnomocnika) ${ }^{12}$.

W innej z kolei sprawie zarówno sąd I instancji, jak i sąd odwoławczy ${ }^{13}$ oddaliły żądanie oparte na art. 24 k.c., które dotyczyło posłużenia się w innej niemieckiej gazecie sformułowaniem ,polski obóz koncentracyjny”. Na uzasadnienie swojego żądania powód wskazał, że

formułowanie nieprawdziwych twierdzeń w świetle historycznych faktów poprzez użycie określenia ,polski obóz koncentracyjny” wobec byłych niemieckich nazistowskich obozów zagłady obraża Naród Polski, godząc w poczucie tożsamości narodowej, prawo do poszanowania prawdy o historii Narodu Polskiego i godności narodowej. Tym samym narusza jego tożsamość narodową, jego prawo do poszanowania prawdy o historii Narodu Polskiego, jako czynnika kształtującego jego tożsamość oraz jego poczucie godności narodowej, czyli poczucie dumy i własnej wartości wynikającej z przynależności do Narodu Polskiego ${ }^{14}$.

Powód podniósł, że formułowanie nieprawdziwych twierdzeń o historii Narodu Polskiego, mimo iż nie zostało skierowane przeciwko konkretnej osobie, spowodowało ingerencję $\mathrm{w}$ jego poczucie dumy i system wartości, zaburzyło jego sferę uczuć wynikającą z utożsamiania się z Narodem Polskim, z wewnętrzną potrzebą dbałości o utrzymanie tych wartości w świadomości wspólnoty narodowej, a ponadto wskazał, że jego dziadek zginął w niemieckim obozie koncentracyjnym. Sąd I instancji wskazał, że prawo do poszanowania prawdy o historii Narodu Polskiego nie stanowi dobra osobistego w myśl art. 24 k.c., albowiem ,jest to wartość uniwersalna, kolektywna, związana z całą wspólnotą narodową, przynależna do Narodu Polskiego jako ogółu, której nie sposób jednoznacznie i wyraźnie powiązać z dobrami osobistymi konkretnej osoby"15. Nieco odmienne zapatrywanie w tym przedmiocie miał rozpoznający apelację sąd odwoławczy, który stwierdził:

11 Wyrok Sądu Apelacyjnego w Krakowie z dnia 22 grudnia 2016 roku, I ACa 1080/16, https:// orzeczenia.ms.gov.pl/content/polskie\$0020obozy/152000000000503_I_ACa_001080_2016_ Uz_2016-12-22_001 (dostęp: 13.08.2020).

12 Ibidem.

13 Wyrok Sadu Apelacyjnego w Warszawie z dnia 31 marca 2016 roku, I ACa 971/15, https:// orzeczenia.ms.gov.pl/content/polskie\$0020obozy/154500000000503_I_ACa_000971_2015_ Uz_2016-03-31_001 (dostęp: 13.08.2020).

${ }^{14}$ Ibidem.

15 Ibidem. 
W ocenie SA dla uznania naruszenia poczucia tożsamości narodowej wskutek wypowiedzi o polskich obozach koncentracyjnych nie jest niezbędne zawarcie $w$ jej treści odniesienia do konkretnej osoby jako wchodzącej w skład polskiej wspólnoty narodowej. W/w wypowiedź godzi wprost w wartości związane z uczestnictwem jednostki w społeczności, w sposób naturalny kształtującej jej osobowość ${ }^{16}$.

Niemniej jednak SA oddalił apelację powoda, uznając, że pozwany dopełnił czynności niezbędnych do usunięcia skutków naruszenia dóbr osobistych, usuwając kłamliwe określenie oraz publikując przeprosiny.

\section{Nowe środki ochrony prawnej}

Nowe środki ochrony prawnej dobrego imienia Rzeczypospolitej Polskiej przynosi nowelizacja ustawy o IPN z dnia 26 stycznia 2018 roku. W przeciwieństwie do dotychczasowego stanu prawnego środki te nie mają charakteru indywidualnego - uprzednio konieczne było bowiem wykazanie naruszenia indywidualnych dóbr osobistych powoda - lecz cechują się uniwersalnością skierowaną na powszechną ochronę wizerunku Polski. Jak już wspomniano, oprócz rozwiązania o charakterze cywilnym pierwotnie został także rozszerzony katalog pozakodeksowych przestępstw zawartych w rozdziale 7 ustawy o IPN $^{17}$ o art. 55a i 55b, dotyczących przestępstwa publicznego i wbrew faktom przypisania Narodowi Polskiemu lub Państwu Polskiemu odpowiedzialności za zbrodnie popełnione przez III Rzeszę Niemiecką ${ }^{18}$. Jednakże po niespełna pół roku przepisy te zostały uchylone, skutkiem czego jedyną drogą ochrony dobrego imienia Polski pozostaje droga cywilna na podstawie rozdziału 6c ustawy o IPN zatytułowanego „Ochrona dobrego imienia Rzeczypospolitej Polskiej i Narodu Polskiego”. Artykuł 530o ustawy stanowi:

Do ochrony dobrego imienia Rzeczypospolitej Polskiej i Narodu Polskiego odpowiednie zastosowanie mają przepisy ustawy z dnia 23 kwietnia 1964 roku — Kodeks cywilny (Dz.U. z 2017 r. poz. 459, 933 i 1132) o ochronie dóbr osobistych. Powództwo o ochronę dobrego imienia Rzeczypospolitej Polskiej lub Narodu Polskiego może wytoczyć organizacja pozarządowa w zakresie swoich zadań statutowych. Odszkodowanie lub zadośćuczynienie przysługują Skarbowi Państwa.

Zgodnie natomiast z art. 53p ustawy „powództwo o ochronę dobrego imienia Rzeczypospolitej Polskiej lub Narodu Polskiego może wytoczyć również Instytut Pamięci Narodowej. W sprawach tych Instytut Pamięci Narodowej ma zdolność sądową". Przepisy te znajdują zastosowanie niezależnie od tego, jakie prawo jest właściwe, o czym stanowi art. 53q ustawy. Jak przytacza w swej opinii J. Wy-

16 Ibidem.

17 Ustawa z dnia 18 grudnia 1998 roku o Instytucie Pamięci Narodowej — Komisji Ścigania Zbrodni przeciwko Narodowi Polskiemu, tekst jedn. Dz.U. z 2019 r. poz. 1882.

18 Zob. więcej na ten temat J. Kluza, Projektowany art. 55 a ustawy o Instytucie Pamięci Narodowej (analiza krytyczna), „Czasopismo Prawa Karnego i Nauk Penalnych” 2016, z. 3, s. 7-25. 
rembak $^{19}$, nie ma wątpliwości co do tego, że idea cywilnoprawnej ochrony dobrego imienia RP jest słuszna, jednak zdaniem tego autora zastrzeżenia budzi wprowadzenie tej regulacji w rozdziale $6 \mathrm{c}$ ustawy o IPN — odpowiedzialność cywilnoprawna za naruszenie dóbr osobistych na zasadach płynących z kodeksu cywilnego może dotyczyć jedynie podmiotów stosunków cywilnoprawnych, a tymi nie są ani Rzeczpospolita Polska, ani Naród Polski. Co prawda art. 33 k.c. stanowi, że Skarb Państwa jest osobą prawną, a na podstawie art. 43 k.c. przepisy o ochronie dóbr osobistych osoby fizycznej znajdują zastosowanie odpowiednio do osób prawnych, jednak nie rozwiązuje to istoty problemu. W przeciwnym razie bowiem odesłanie do przepisów kodeksu cywilnego zawarte w ustawie o IPN byłoby bezprzedmiotowe. Skarb Państwa zastępuje państwo w stosunkach cywilnoprawnych, lecz jego funkcja opiera się przede wszystkim na stosunkach majątkowych związanych z majątkiem przysługującym państwu ${ }^{20}$.

Ustawa nakazuje zatem odpowiednie stosowanie przepisów kodeksu cywilnego o ochronie dóbr osobistych. Używanie klauzuli odpowiedniości ma na celu skracanie tekstu prawnego i zapewnienie jego spójności ${ }^{21}$, jednak posługiwanie się takim odesłaniem może mieć różnoraki charakter. W doktrynie bowiem wyróżnia się trzy kategorie odpowiedniego stosowania przepisów: stosowanie wprost, stosowanie z pewnymi zmianami oraz ich niestosowanie ${ }^{22}$. Z powodu częściowego jedynie unormowania omawianej kwestii w art. 53o ustawy należy stwierdzić, że odesłanie zawarte $\mathrm{w}$ tym przepisie nakazuje odpowiednie stosowanie przepisów kodeksu cywilnego zgodnie z zasadą mutatis mutandis (,zmieniając to, co powinno być zmienione"). Przede wszystkim zastosowanie znajdą przepisy art. 23 i 24 k.c. Na podstawie przepisów rozdziału 6c ustawy o IPN oraz art. 23 i 24 k.c. stosowny pozew będzie mogła złożyć organizacja pozarządowa w zakresie swoich zadań statutowych oraz Instytut Pamięci Narodowej. Uprawnienie to nie przysługuje pojedynczym osobom fizycznym. W dalszym jednak ciągu takie osoby będą mogły dochodzić ochrony własnych dóbr osobistych, w tym jednak wypadku konieczne będzie ustalenie, tak jak to miało miejsce dotychczas, że doszło do naruszenia ich indywidualnego dobra osobistego. Gdy z powództwem występuje organizacja po-

19 J. Wyrembak (Biuro Analiz Sejmowych), Opinia prawna w sprawie projektu ustawy o zmianie ustawy o Instytucie Pamięci Narodowej - Komisji Ścigania Zbrodni przeciwko Narodowi Polskiemu, ustawy o grobach i cmentarzach wojennych, ustawy o muzeach, ustawy o odpowiedzialności podmiotów zbiorowych za czyny zabronione pod groźbą kary oraz ustawy o zakazie propagowania komunizmu lub innego ustroju totalitarnego przez nazwy budowli, obiektów i urządzeń użyteczności publicznej (druk sejmowy nr 806), s. 1-2.

20 A. Olejniczak, Z. Radwański, Prawo cywilne - część ogólna, Warszawa 2017, s. 197.

21 A. Kozak, Odsylanie do przepisu zawierajacego upoważnienie ustawowe przez użycie sformułowania „przepisy stosuje się odpowiednio”, http://www.rcl.gov.pl/sites/zalaczniki/artykul_23. pdf.; zob. też § 156 rozporządzenia Prezesa Rady Ministrów z dnia 20 czerwca 2002 roku w sprawie „Zasad techniki prawodawczej”, tekst jedn. Dz.U. z 2016 r. poz. 283.

${ }^{22}$ M. Kosiarski, Zakres stosowania analogii legis w prawie administracyjnym (część I), „Kwartalnik Prawa Publicznego” 2003, nr 1, s. 44-45. 
zarządowa lub IPN, wystarczające jest jedynie wykazanie, że zachowanie pozwanego narusza dobre imię Rzeczypospolitej Polskiej. Organizacja pozarządowa musi ponadto wykazać, że do jej zadań statutowych należy dbanie o dobre imię Polski. Na podstawie art. 24 § 1 k.c. powód może żądać zaniechania naruszeń, dopełnienia czynności potrzebnych do usunięcia skutków naruszenia oraz zadośćuczynienia pieniężnego lub zapłaty odpowiedniej sumy na wskazany cel społeczny, a na podstawie art. $24 \S 2$ k.c. także naprawienia szkody na zasadach ogólnych. W tym jednak zakresie art. 53o ustawy w zdaniu drugim stanowi, że odszkodowanie lub zadośćuczynienie przysługują Skarbowi Państwa. Na tym tle pojawia się wątpliwość, czy przepis art. 53o ustawy o IPN wyłącza możliwość żądania zapłaty określonej sumy na wskazany cel społeczny. Z kategorycznego sformułowania przepisu ustawy o IPN wynika jednak, że odpowiednie stosowanie przepisów k.c. w tym wypadku będzie oznaczać stosowanie przepisu art. 24 § 1 k.c. z takimi zmianami, jakie wynikają z przepisu odsyłającego. Skoro przepis ten stanowi, że odszkodowanie i zadośćuczynienie przysługują wyłącznie Skarbowi Państwa, to nie jest możliwe zasądzanie w sprawie kwoty na cel społeczny. Należy w tym miejscu wskazać, że w dalszym ciągu do ewentualnej odpowiedzialności odszkodowawczej pozwanego konieczne jest spełnienie ogólnych przesłanek tej odpowiedzialności płynących z kodeksu cywilnego, a więc musi powstać szkoda, która pozostaje w adekwatnym związku przyczynowym z działaniem sprawcy (art. 24 § 2 w związku z art. $361 \S 1$ i 2 k.c.). Trudności z tym związane dostrzega także projektodawca, który w uzasadnieniu projektu wskazuje:

W aktualnym stanie prawnym koncepcja kierowania roszczeń o charakterze ściśle odszkodowawczym (o naprawienie szkody majątkowej) wobec podmiotów używających przedmiotowych sformułowań wydaje się wątpliwa z uwagi na niemożność wykazania uszczerbku w majątku państwowym $^{23}$.

Z tego powodu wyłączenie przez ustawodawcę możliwości zasądzenia dodatkowego świadczenia na cel społeczny, chociażby związany z działalnością organizacji pozarządowej wnoszącej pozew, wydaje się nieuzasadnione. Za dopuszczalnością zasądzenia świadczenia na cel społeczny opowiada jednak się Ministerstwo Kultury i Dziedzictwa Narodowego, które w toku opiniowania projektu ustawy stwierdziło, że

wykorzystywanie cywilnoprawnych środków do dochodzenia wszelkich roszczeń powstałych w związku z naruszaniem dobrego imienia (w tym zadośćuczynienia pieniężnego czy zapłaty odpowiedniej sumy pieniężnej na wskazany cel społeczny) powinno stanowić narzędzie skuteczne i adekwatne w stosunku do danej grupy podmiotów ${ }^{24}$.

23 Uzasadnienie druku sejmowego nr 806 (Sejm VIII kadencji), s. 9.

24 Stanowisko Ministerstwa Kultury i Dziedzictwa Narodowego w przedmiocie projektu ustawy o zmianie ustawy o Instytucie Pamięci Narodowej - Komisji Ścigania Zbrodni przeciwko Narodowi Polskiemu oraz ustawy o odpowiedzialności podmiotów zbiorowych za czyny zabronione pod groźbą kary, DL.246/16, s. 2-3. 
$\mathrm{W}$ odniesieniu do zasygnalizowanego już problemu związanego $\mathrm{z}$ istnieniem dóbr osobistych przynależnych Rzeczypospolitej Polskiej oraz Narodowi Polskiemu należy zwrócić uwagę na stanowisko Prezesa Rządowego Centrum Legislacji (RCL), który w toku opiniowania projektu ustawy wskazywał na bezprzedmiotowość odesłania do przepisów kodeksu cywilnego o ochronie dóbr osobistych. Prezes RCL podkreśla brak adekwatnych przepisów merytorycznych dotyczących zasad ochrony dobrego imienia $\mathrm{RP}^{25}$. Sygnalizuje także wątpliwości związane z upoważnieniem IPN do składania powództwa na tej podstawie ze względu na naruszenie kompetencji Prokuratorii Generalnej Rzeczypospolitej Polskiej do zastępowania Skarbu Państwa przed sądami powszechnymi ${ }^{26}$. Zgodnie z art. 1 ust. 1 ustawy o Prokuratorii Generalnej $\mathrm{RP}^{27}$ stoi ona na straży praw i interesów Rzeczypospolitej Polskiej, w tym praw i interesów Skarbu Państwa, oraz mienia państwowego nienależącego do Skarbu Państwa. Artykuł 4 ust. 1 pkt 1 i 2 stanowią natomiast, że do zadań Prokuratorii Generalnej należy: (1) wyłączne zastępstwo Skarbu Państwa przed Sądem Najwyższym; (2) zastępstwo Skarbu Państwa przed sądami powszechnymi i polubownymi. Jak wynika z brzmienia przywołanych punktów 1 i 2, charakter wyłącznego zastępstwa, a więc bez możliwości przekazania tej funkcji innemu podmiotowi, dotyczy jedynie zastępstwa przed Sądem Najwyższym. Przed sądami powszechnymi zastępstwo takie nie ma charakteru bezwzględnego, a więc w tym zakresie nowelizacja wprowadzająca do art. 1 ustawy o IPN pkt 2a, rozszerzający zakres działania IPN o ochronę dobrego imienia Rzeczypospolitej Polskiej i Narodu Polskiego, nie pozostaje w sprzeczności z regulacją dotyczącą Prokuratorii Generalnej. Co prawda inne zdanie w tym zakresie wyraził Prezes IPN, ale jest to stanowisko błędne, co zostało wymownie skomentowane przez nieznanego przedstawiciela Ministerstwa Sprawiedliwości na marginesie pisma w toku opiniowana projektu ustawy ${ }^{28}$. Ponadto należy stwierdzić, że argument ten stoi w sprzeczności z wcześniej postulowanym — jeśli bowiem w sprawach o ochronę dobrego imienia Polski wyłącznie właściwa powinna być Prokuratoria Generalna, to tym samym należałoby uznać, że Polska i Naród Polski posiadają dobra osobiste, do czego sceptycznie odnosił się wcześniej prezes RCL.

25 Uwagi do projektu J. Rusinak, Prezes Rządowego Centrum Legislacji, RCL.DPA.550.6/2016, s. $1-2$.

${ }^{26}$ Ibidem, s. 2. Opinia była formułowana na gruncie poprzednio obowiązującej ustawy z dnia 8 lipca 2005 roku o Prokuratorii Generalnej Skarbu Państwa, tekst jedn. Dz.U. z 2016 r. poz. 1313, której Prokuratoria Generalna Rzeczypospolitej Polskiej jest następcą prawnym.

27 Ustawa z dnia 15 grudnia 2016 roku o Prokuratorii Generalnej Rzeczypospolitej Polskiej, Dz.U. poz. 2261.

${ }^{28}$ Uwagi do projektu ustawy zgłaszane przez Ł. Kamińskiego, Prezesa Instytutu Pamięci Narodowej, BPR-0241-1(4)/16, http://legislacja.rcl.gov.pl/docs//2/12282660/12339404/12339407/ dokument210313.pdf (dostęp: 13.08.2020). 
Z kolei Sąd Najwyższy w swoim stanowisku ${ }^{29}$ do projektu podnosił problem związany z regulacją międzynarodową zawartą w art. 53q ustawy, który stanowi: „Przepisy art. 53o i art. 53p mają zastosowanie niezależnie od tego, jakie prawo jest właściwe". Jak wynika z uzasadnienia projektu, jest on zgodny z prawem unijnym, albowiem nie narusza zasad jurysdykcji i uznawania orzeczeń sądowych oraz ich wykonywania w sprawach cywilnych i handlowych ${ }^{30}$, a także jest wyłączony spod zakresu unijnego prawa właściwego dla zobowiązań pozaumownych ${ }^{31}$. Natomiast zgodnie z art. 16 ust. 1 prawa prywatnego międzynarodowego ${ }^{32}$ dobra osobiste osoby fizycznej podlegają jej prawu ojczystemu, a osoba fizyczna, której dobro osobiste jest zagrożone naruszeniem lub zostało naruszone, może żądać ochrony na podstawie prawa państwa, na którego terytorium nastąpiło zdarzenie powodujące to zagrożenie naruszenia lub naruszenie, albo prawa państwa, na którego terytorium wystąpiły skutki tego naruszenia, a jeżeli do naruszenia dobra osobistego osoby fizycznej doszło w środkach społecznego przekazu, o prawie do odpowiedzi, sprostowania lub innego podobnego środka ochronnego rozstrzyga prawo państwa, w którym ma siedzibę, albo miejsce zwykłego pobytu nadawcy lub wydawcy (art. 16 ust. 2 i 3 p.p.m.). Gdyby jednak uznać słuszność tego stanowiska, przepis art. 53q byłby bezprzedmiotowy, ponieważ wystarczające byłoby w tym zakresie odpowiednie stosowanie przepisów ustawy prawo prywatne międzynarodowe. W tym zakresie SN podnosi, że wyłączenie, o którym mowa w rozporządzeniu Rzym II, dotyczy dóbr osobistych ujętych personalnie, podczas gdy polska regulacja obejmuje swym zakresem naruszenie dóbr generalnych zbiorowości, jaką reprezentuje Rzeczpospolita Polska i Naród Polski.

\section{Zakończenie}

Niezaprzeczalnie ustawa dotyka kwestii ważnej z punktu widzenia polskiej racji stanu. Ze względu jednak na złożoność problematyki leżącej u podłoża tej nowelizacji jej prawne uregulowanie jest również niesłychanie trudne i to na gruncie prawa zarówno karnego, jak i cywilnego. Uznanie jednak słuszności prawnej regulacji kwestii związanej z zakłamywaniem historii, co ma zresztą miejsce

29 Sąd Najwyższy. Biuro Studiów i Analiz, BSA II-021/57/16. Uwagi do projektu ustawy o zmianie ustawy o Instytucie Pamięci Narodowej - Komisji Ścigania Zbrodni przeciwko Narodowi Polskiemu oraz ustawy o odpowiedzialności podmiotów zbiorowych za czyny zabronione pod groźbą kary, s. 3.

30 Rozporządzenie Parlamentu Europejskiego i Rady (UE) nr 1215/2012 z dnia 12 grudnia 2012 roku w sprawie jurysdykcji i uznawania orzeczeń sądowych oraz ich wykonywania w sprawach cywilnych i handlowych, Dz.U. UE z 2012 r., L 351/1.

31 Rozporządzenie Parlamentu Europejskiego i Rady(WE) nr 864/200 z dnia 11 lipca 2007 roku dotyczące prawa właściwego dla zobowiązań pozaumownych („Rzym II”), Dz.U. UE z 2007 r., L 199/40.

32 Ustawa z dnia 4 lutego 2011 roku Prawo prywatne międzynarodowe, tekst jedn. Dz.U. z 2015 r. poz. 1792; dalej: p.p.m. 
w wielu innych krajach, nie może przesądzać per se o jednoznacznie pozytywnej ocenie tej regulacji. Wprowadzone bowiem na mocy noweli ustawy o IPN cywilne środki ochrony dobrego imienia Rzeczypospolitej Polskiej oraz Narodu Polskiego cechują się wieloma mankamentami, które mogą wymiernie utrudnić ich funkcjonowanie. Już pierwsze przepisy nowego rozdziału budzą wątpliwości, czy tym podmiotom przysługują $\mathrm{w}$ ogóle dobra osobiste — podmioty te nie stanowią bowiem podmiotów prawa cywilnego. Podmiotem prawa cywilnego jest co prawda Skarb Państwa, jednak jest to fikcyjna konstrukcja prawna. Odpowiednim uregulowaniem tej kwestii, postulowanym w toku opiniowania projektu ustawy i niebudzącym wątpliwości, będzie takie brzmienie przepisu, które wprost stanowiłoby, że Rzeczypospolitej Polskiej przysługuje ochrona należnych jej dóbr osobistych. Problematyczne będzie także praktyczne stosowanie znowelizowanych przepisów. Nie ulega wątpliwości, że celem ustawy było ograniczenie kłamliwych wypowiedzi mających miejsce przede wszystkim za granicą. W tym zakresie jednak skuteczność orzeczeń na gruncie tej ustawy i ich uznawalność za granicą nie jest oczywista. W końcu trzeba też zwrócić uwagę, że cywilne środki, o jakich mowa w rozdziale 6c ustawy o IPN, w swej istocie zmierzają do penalizowania czynności zniesławiających dobre imię Polski i Narodu Polskiego, wobec czego można mieć wątpliwości, czy jest to rola adekwatna do norm prawa cywilnego.

\section{Bibliografia}

\section{Akty prawne}

Rozporządzenie Parlamentu Europejskiego i Rady (UE) nr 864/200 z dnia 11 lipca 2007 roku dotyczące prawa właściwego dla zobowiązań pozaumownych („,Rzym II”), Dz.U. UE z 2007 r., L 199/40.

Rozporządzenie Parlamentu Europejskiego i Rady (UE) nr 1215/2012 z dnia 12 grudnia 2012 roku w sprawie jurysdykcji i uznawania orzeczeń sądowych oraz ich wykonywania w sprawach cywilnych i handlowych, Dz.U. UE z 2012 r., L 351/1.

Rozporządzenie Prezesa Rady Ministrów z dnia 20 czerwca 2002 roku w sprawie „Zasad techniki prawodawczej”, tekst jedn. Dz.U. z 2016 r. poz. 283.

Ustawa z dnia 26 stycznia 1984 roku Prawo prasowe, Dz.U. Nr 5, poz. 24.

Ustawa z dnia 18 grudnia 1998 roku o Instytucie Pamięci Narodowej — Komisji Ścigania Zbrodni przeciwko Narodowi Polskiemu, tekst jedn. Dz.U. z 2019 r. poz. 1882.

Ustawa z dnia 4 lutego 2011 roku Prawo prywatne międzynarodowe, tekst jedn. Dz.U. z 2015 r. poz. 1792.

Ustawa z dnia 15 grudnia 2016 roku o Prokuratorii Generalnej Rzeczypospolitej Polskiej, Dz.U. poz. 2261.

Ustawa z dnia 26 stycznia 2018 roku o zmianie ustawy o Instytucie Pamięci Narodowej — Komisji Ścigania Zbrodni przeciwko Narodowi Polskiemu, ustawy o grobach i cmentarzach wojennych, ustawy o muzeach oraz ustawy o odpowiedzialności podmiotów zbiorowych za czyny zabronione pod groźbą kary, Dz.U. poz. 369. 
Ustawa z dnia 27 czerwca 2018 roku o zmianie ustawy o Instytucie Pamięci Narodowej — Komisji Ścigania Zbrodni przeciwko Narodowi Polskiemu oraz ustawy o odpowiedzialności podmiotów zbiorowych za czyny zabronione pod groźbą kary, Dz.U. poz. 1277.

\section{Literatura}

Kluza J., Projektowany art. 55 a ustawy o Instytucie Pamięci Narodowej (analiza krytyczna), „Czasopismo Prawa Karnego i Nauk Penalnych" 2016, z. 3.

Kosiarski M., Zakres stosowania analogii legis w prawie administracyjnym (część I), „Kwartalnik Prawa Publicznego" 2003, nr 1.

Kozak A., Odsyłanie do przepisu zawierajacego upoważnienie ustawowe przez użycie sformułowania ,przepisy stosuje się odpowiednio”, http://www.rcl.gov.pl/sites/zalaczniki/artykul_23.pdf.

Olejniczak A., Radwański Z., Prawo cywilne - część ogólna, Warszawa 2017.

Pazdan M., [w:] Kodeks cywilny, t. 1. Komentarz. Art. 1-44910, red. K. Pietrzykowski, Warszawa 2015.

Sąd Najwyższy. Biuro Studiów i Analiz, BSA II-021/57/16. Uwagi do projektu ustawy o zmianie ustawy o Instytucie Pamięci Narodowej — Komisji Ścigania Zbrodni przeciwko Narodowi Polskiemu oraz ustawy o odpowiedzialności podmiotów zbiorowych za czyny zabronione pod groźbą kary.

Stanowisko Ministerstwa Kultury i Dziedzictwa Narodowego w przedmiocie projektu ustawy o zmianie ustawy o Instytucie Pamięci Narodowej — Komisji Ścigania Zbrodni przeciwko Narodowi Polskiemu oraz ustawy o odpowiedzialności podmiotów zbiorowych za czyny zabronione pod groźbą kary, DL.246/16.

Uwagi do projektu J. Rusinak, Prezes Rządowego Centrum Legislacji, RCL.DPA.550.6/2016, http:// legislacja.rcl.gov.pl/docs//2/12282660/12339404/12339407/dokument210313.pdf.

Uwagi do projektu ustawy zgłaszane przez Ł. Kamińskiego, Prezesa Instytutu Pamięci Narodowej, BPR-0241-1(4)/16, http://legislacja.rcl.gov.pl/docs//2/12282660/12339404/12339407/dokument210313.pdf.

Wyrembak J. (Biuro Analiz Sejmowych), Opinia prawna w sprawie projektu ustawy o zmianie ustawy o Instytucie Pamięci Narodowej - Komisji Ścigania Zbrodni przeciwko Narodowi Polskiemu, ustawy o grobach i cmentarzach wojennych, ustawy o muzeach, ustawy o odpowiedzialności podmiotów zbiorowych za czyny zabronione pod groźbą kary oraz ustawy o zakazie propagowania komunizmu lub innego ustroju totalitarnego przez nazwy budowli, obiektów i urządzeń użyteczności publicznej (druk sejmowy nr 806).

\section{Orzecznictwo}

Wyrok Sądu Apelacyjnego w Krakowie z dnia 22 grudnia 2016 roku, I ACa 1080/16, https:// orzeczenia.ms.gov.pl/content/polskie\$0020obozy/152000000000503_I_ACa_001080_2016_ Uz_2016-12-22_001.

Wyrok Sądu Apelacyjnego w Warszawie z dnia 31 marca 2016 roku, I ACa 971/15, https://orzeczenia.ms.gov.pl/content/polskie\$0020obozy/154500000000503_I_ACa_000971_2015_Uz_201603-31_001.

Wyrok Sądu Okręgowego w Krakowie z dnia 26 kwietnia 2016 roku, I C 151/14, https://orzeczenia. ms.gov.pl/content/polskie $\$ 0020$ obozy/152010000000503_I_C_000151_2014_Uz_2016-0425_001. 